\title{
Kewirausahaan bagi pengungsi asing dan pencari suaka di Pekanbaru pada masa pandemi Covid-19
}

\author{
Ahmad Jamaan, Muhammad Saeri, Yessi Olivia, Yusnarida Eka Nizmi, \& Irwan Iskandar*, \\ Universitas Riau \\ *irwan.iskandar@lecturer.unri.ac.id
}

\begin{abstract}
Abstrak. Para pengungsi asing di Pekanbaru memiliki masalah-masalah baik secara eksternal maupun secara internal. Secara eksternal, para pengungsi tersebut memiliki hambatan dalam beradaptasi dengan lingkungan sosial masyarakat dimana mereka ditampung. Secara internal, mereka memiliki kemampuan ekonomi yang kurang, padahal di antara mereka berprofesi sebagai dosen, pengacara, jurnalis, seniman dan koki. Untuk itu, sebagai wadah adaptasi dengan masyarakat sekitar dan upaya penguatan ekonomi, kegiatan kewirausahaan dalam bentuk pengabdian kepada masyarakat diadakan. Tujuan kegiatan ini adalah untuk adaptasi para pengungsi dengan masyarakat sekitar dan untuk menggali potensi ekonomi para pengungsi. Kegiatan pengabdian masyarakat ini dilaksanakan dengan pemberian motivasi kewirausahaan, pendampingan pembuatan produk berciri khas negara asal para pengungsi dan pengenalan serta pemasaran produk kewirausahaan tersebut. Sebagai hasilnya, kegiatan pengabdian telah sukses mengadakan pameran dan memasarkan produk dalam bentuk produk kuliner dan lukisan pada perayaan Hari Ulang Tahun Republik Indonesia pada tanggal 17 Agustus 2020. Meskipun demikian, kegiatan tersebut tidak dapat dihadiri oleh para pengungsi dan pencari suaka karena tidak memperoleh izin seiring Pandemi COVID-19 di Pekanbaru.
\end{abstract}

Kata kunci: pengabdian masyarakat, kemandirian, pendampingan kewirausahaan, pengungsi, pencari suaka

\begin{abstract}
The existence of foreign refugees in Pekanbaru has had an external impact on the social environment of the society in which they are accommodated. Internally, the prohibition of refugees to work formally, it has had the impact of reducing the economic capacity of the refugees itself. Even though, many of them while in their home countries have special professions such as lecturer, lawyer, journalist, and others. Dealing with this reason, in order to strengthen the economy for refugees in Pekanbaru, community service activities are held in the form of introducing and exploring the potential of refugees, socializing the existence of refugees to the society, and entrepreneurship assistance. The activity of entrepreneurship is implemented through three components, namely entrepreneurial motivation, assistance in making products characterized by the country of origin of refugees and the introduction and marketing of these entrepreneurial products. Thus, this community service activities can provide the business independence for refugees in making culinary products and painting crafts. In its implementation, this community service could run well without the presence of refugees and asylum seekers because of absence of permission during Pandemic COVID-19 in Pekanbaru.
\end{abstract}

Keywords: community service, independence, entrepreneurship assistance, refugees, asylum seekers

To cite this article: Jamaan, A., M. Saeri., Y. Olivia., Y. E. Nizmi., \& I. Iskandar. 2020. Kewirausahaan bagi pengungsi asing dan pencari suaka di Pekanbaru pada masa pandemi Covid-19. Unri Conference Series: Community Engagement 2: 275-280. https://doi.org/10.31258/unricsce.2.275-280

\section{(C) 2020 Authors}

Peer-review under responsibility of the organizing committee of Seminar Nasional Pemberdayaan Masyarakat 2020 


\section{PENDAHULUAN}

Krisis kemanusiaan di dunia telah berimbas terhadap Indonesia dimana hingga April 2019 tercatat lebih dari 13.840 pengungsi dan pencari suaka di seluruh wilayah nusantara. (https://kemlu.go.id/portal/id/read/88/halaman_list_lainnya/isu-isu-kemanusiaan) Jumlah ini menurun dari jumlah 13.900 di seluruh Indonesia pada tahun 2018. Para pengungsi dan pencari suaka tersebut berasal dari Afghanistan (mayoritas pengungsi di Indonesia), Somalia, Iraq, Nigeria, Sri Lanka, Myanmar, dan sebagainya. (https://www.liputan6.com/global/read/4019232/nasib-pengungsi-terlunta-lunta-di-indonesia-ditolak-negeriimpian\#: :text=Jumlah\%20Pengungsi\%20di\%20Indonesia,yang\%20berjumlah\%20sekitar\%2014.300\%20or ang) Pada tahun 2019, para pengungsi sementara ditampung di 13 rumah detensi di Indonesia (Rudenim), seperti Jakarta, Makassar, Medan, Pekanbaru, Kupang, Surabaya, Batam, Tanjungpinang, dan Semarang. Di antara daerah-daerah tersebut, Pekanbaru termasuk 4 (empat) besar menampung pengungsi dan pencari suaka. (https://www.validnews.id/Infografis-Deteni-dan-Pengungsi-13-Rudenim-di-Indonesia-dv).

Pada bulan Juli 2019, Rudenim Pekanbaru dan 5 tempat penampungan lainnya telah menampung 1.028 orang (https://www.suara.com/news/2019/07/02/133526/ratusan-anak-imigran-di-pekanbaru-akanditampung-di-sekolah-negeri?page=all) Angka ini menurun di tahun 2020, menjadi 976 orang yang berada dalam pengawasan Rudenim. (https://www.goriau.com/berita/baca/100-pengungsi-di-pekanbaru-demorudenim-minta-perbaikan-

fasilitas.html\#: :text=Jumlah\%20pengungsi\%20di\%20Pekanbaru\%20kini,tempat\%20sudah\%20terakomodir \%2C\%E2\%80\%9D\%20katanya)

Keberadaan pengungsi dan pencari suaka di Pekanbaru turut menyebabkan banyak persoalan. Mulai dari persoalan identitas, kepastian hukum, kepastian status sebagai orang asing di negara transit, persoalan kesehatan, adaptasi dengan lingkungan sosial, serta terbatasnya akses pendidikan dan izin bekerja. Khusus dari aspek pendidikan, banyak anak-anak pengungsi dan pencari suaka usia sekolah yang tidak mendapatkan akses pendidikan yang maksimal dan setara sebagaimana yang didapatkan oleh Warga Negara Indonesia secara umum. Implikasinya telah menyebabkan rendahnya kualitas pendidikan mereka. Padahal pendidikan diperlukan untuk mendapatkan akses bagi dunia kerja. Larangan bekerja terhadap pengungsi dan pencari suaka turut menyebabkan rendahnya kemampuan mereka membiayai kehidupan. (https://ugm.ac.id/id/berita/16407akses.pekerjaan.krusial.bagi.pengungsi)

Selain akses pendidikan dan izin kerja yang rumit, interaksi para pengungsi terhambat dalam berbicara Bahasa Indonesia atau pun Bahasa Inggris (linguistik). Kondisi ini berakibat fatal bagi karir mereka di masa depan. Kurangnya fasilitas kesehatan, terbatasnya kebebasan untuk berekspresi, berinteraksi, dan beragama juga berdampak pada kondisi psikis para pengungsi yang memunculkan terjadinya tindakan kriminal pelacuran dan perdagangan narkoba. Hal ini tentunya tidak hanya membahayakan kehidupan para pengungsi dan pencari suaka dan juga masyarakat lokal di sekitar mereka.

Persoalan yang tengah dihadapi pengungsi dan pencari suaka yang berada di Pekanbaru tersebut tentunya harus diurai. Untuk menjawab personalan yang disebutkan, kegiatan pengabdian masyarakat ini menawarkan solusi yang aplikatif. Kegiatan yang berupa pelatihan dan pendampingan kewirausahaan bagi pengungsi diharapkan dapat meningkatkan kemampuan bertahan mereka di tengah tantangan global abad-21.

Selain menjadi wadah sosialisasi dan komunikasi pengungsi dan pencari suaka dengan warga setempat, kegiatan pengabdian ini bertujuan meningkatkan potensi ekonomi para pengungsi sebagai implementasi tujuan pembangunan berkelanjutan 2030.

\section{Kerangka pemikiran pelatihan dan pendampingan kewirausahaan}

Kegiatan pelatihan dan pendampingan berbentuk kelas yang ditujukan untuk meningkatkan kreatifitas dan kemampuan pengungsi dan pencari suaka dari kalangan pengungsi usia produktif. Kegiatan ini didesain berdasarkan kemampuan yang seharusnya mereka miliki di masa Revolusi Industri 4.0 sebelum terjun ke dunia kerja di negara tujuan.

Materi yang disampaikan dalam kegiatan pengabdian masyarakat ini mengandung upaya-upaya; memecahkan masalah yang kompleks, berfikir kritis dan kognitif, bertanggungjawab dan jujur, melayani, menjaga kualitas produk, berkoordinasi dengan orang lain, meningkatkan kecerdasan emosional, menilai dan mengambil keputusan, bernegosiasi, fleksibilitas, mampu dalam mengatur keuangan secara tepat dan akurat, serta pemasaran secara terintegrasi.

Kegiatan pengabdian masyarakat ini dapat dipilah atas pelatihan yang ditinjau dari aspek sosial budaya. Kegiatan ini berupa pelatihan pelatihan wirausaha dan penguatan integrasi social. Dari aspek bantuan teknis, 
dilaksanakan pemaparan, penyediaan sarana berusaha dan dan pemasarannya. Kegiatan pendampingan dilakukan dalam rangka dalam menghasilkan produk nyata dan dapat diperdagangkan secara sah sehingga mampu meningkatkan proses interaksi mereka dengan warga sekitar serta menyelesaikan persoalan ekonomi mereka sendiri secara temporer. Lebih lanjut, tujuan dari implementasi pengabdian masyarakat ini adalah pendampingan kewirausahaan untuk kelompok usia produktif para imigran dan pencari suaka yang berada di Pekanbaru sehingga mampu mensejahterakan mereka.

Dengan demikian, dalam menjalankan aktivitas sehari-harinya, para pengungsi dan pencari suaka mampu berinteraksi dan beradaptasi dengan masyarakat setempat dengan memperhatikan aturan dan tatanan sosial yang berlaku, serta mampu menciptakan peluang usaha lebih besar sehingga memberikan peningkatan perekonomian mereka.

\section{METODE PENERAPAN}

Dalam pelaksanaannya, kegiatan pengabdian ini menempuh beberapa tahapan, yakni:

\section{a. Tahapan persiapan}

Pada tahapan ini melakukan identifikasi dan inventarisasi lokasi dan penerima manfaat pengabdian masyarakat. Adapun yang diidentifikasi adalah kondisi sosial, budaya, dan ekonomi penerima manfaat; serta kelembagaan pendukung para pengungsi dan pencari suaka.

Pada tahapan ini akan dilakukan beberapa aktivitas. Pertama, mengidentifikasi kondisi penerima manfaat. Identifikasi/inventarisasi kondisi sosial-budaya penerima manfaat (beneficeries) mencakup pengumpulan data yang menggambarkan karakteristik dan aktivitas sosial, atribut-atribut budaya kerja dan seni-budaya serta potensi yang ada dan dimiliki pengungsi dan pencari suaka, khususnya tentang sistem atau aturan-aturan yang di keseharian mereka. Sebagai satu kesatuan, dilakukan inventarisasi kondisi ekonomi yang mencakup sumbersumber pendapatan (jenis usaha) dan pengeluaran, dan alokasi waktu kerja baik pada usaha utama maupun usaha sampingan. Lebih jauh kondisi ekonomi mencakup perolehan gambaran tentang ketersediaan, harga dan kualitas dari prasarana/sarana produksi produksi, dan aspek pasar/pemasaran dari komoditas yang mungkin diusahakan.

Kedua, kondisi para pengungsi dan pencari suaka. Identifikasi/inventarisasi kondisi usia produktif pengungsi dan pencari suaka dilakukan untuk memperoleh data dan informasi tentang jenis kelamin, asal, aktivitas sehari-hari, kecenderungan beraktivitas, kendala dalam bersosialisasi, harapan dan peluang yang ingin diraih, serta interaksi mereka dengan masyarakat tempatan. Ketiga, mengidentifikasi kelembagaan pendukung. Kegiatan inventarisasi/identifikasi terhadap kelembagaan mencakup pengumpulan data dari kondisi yang ada, meliputi: (1) jumlah kelembagaan yang terlibat aktif dalam membantu pengungsi dan aktivitas dilakukan, (2) kelembagaan internasional dan aktivitas yang dilakukan (IOM, UNHCR, Pemda, imigrasi, LSM). (3) kelembagaan sarana produksi dan pemasaran.

Pada tahapan ini juga dilakukan penyusunan program kerja yang berupa penyusunan rencana aksi yang akan dilakukan dalam tahapan pelaksanaan dan sosialisasi.

\section{b. Tahapan pelaksanaan berbentuk sosialisasi dan pendampingan kewirausahaan serta pemasaran produk}

Pada tahapan kegiatan sosialisasi ini Pandemi COVID-19 mulai berdampak kepada Indonesia, terutama di Pekanbaru. Sejak itu, kegiatan sosialisai dilakukan bersama UNHCR dan IOM secara online (dalam jaringan) melalui aplikasi Zoom tanpa para pengungsi dan pencari suaka. Ketidakterlibatan mereka dalam kegiatan sosialisasi untuk menghindari dampak Pandemi terhadap kondisi

Begitu pun kegiatan pendampingan kewirausahaan dan pemasaran produk dilaksanakan secara online dan berkomunikasi melalui seorang perwakilan pengungsi dan pencari suaka. Metode ini ditempuh karena wilayah Pekanbaru terkategori zona merah, sehingga IOM tidak memberikan izin pelaksanaa kegiatan tatap muka, berkumpul dan melibatkan langsung para imigran. Pada tahapan pemasaran produk diadakan pameran dan sekaligus penjualan produk kuliner dan lukisan para pengungsi pada perayaan peringatan Hari Kemerdekaan Republik Indonesia pada tanggal 17 Agustus 2020.

\section{c. Tahapan Evaluasi dan Pelaporan}

Tahapan melakukan kegiatan monitoring dan evaluasi dimulai dari awal (persiapan), pelaksanaan, dan hasil akhir yang dicapai monitoring dan evaluasi ini dilakukan terutama terhadap monitoring dan evaluasi terhadap 
program yang dilaksanakan. Adapun fokus evaluasi dan monitoring dilakukan terhadap kegiatan pendampingan secara keseluruhan.

Evaluasi melalui capaian kinerja yang diliahat dari indikator evaluasi (motivasi, kompetensi, peran) yang dimiliki dan hasil yang dicapai oleh peserta pengabdian masyarakat. Evaluasi yang dilakukan terhadap keberhasilan dan kegagalan pendampingan, berupa faktor yang sangat menentukan/berpengaruh terhadap keberhasilan dan kegagalan kegiatan. Evaluasi ini dilakukan dengan menggunakan indikator yang disusun dan digunakan dalam keberhasilan pendampingan.

Pertama keterlibatan pengungsi untuk berpartisipasi aktif dalam kegiatan ini. Walaupun ada keterbatasan interaksi akibat status yang mereka miliki ditambah dengan persoalan virus Covid-19 yang membatasi interaksi masyarakat dalam berkumpul, akan tetapi respon dan keterlibatan mereka untuk mau berpartisipasi aktif dalam kegiatan ini menjadi alat ukur keberhasilan. Ini dapat diukur dari beberapa hal. Pertama, dari kesediaan mereka untuk diinterview baik untuk kegiatan sosialisasi kegiatan, pemberian informasi keberadaan mereka di Pekanbaru, interaksi mereka dengan masyarakat tempat mereka dikumpulkan. Walaupun sifatnya lebih kepada perwakilan, akan tetapi antusiasme mereka untuk dapat terlibat dalam kegiatan ini cukup tinggi.

Kedua, adanya kesediaan mereka untuk menyiapkan sejumlah produk ciri khas negara mereka untuk diperkenalkan kepada masyarakat Pekanbaru sekaligus untuk diperjualbelikan.. Misalnya makanan seperti makanan nasi Basmati dan nasi Briyani, juga produk kreativitas seni seperti lukisan.

Ketiga, komitmen, dukungan dan partisipasi lembaga internasional yang membawahi dan melindungi keberadaan pengungsi di Pekanbaru, UNHCR dan IOM. Keterlibatan dan bantuan kedua lembaga internasional ini dalam kegiatan untuk pengungsi menjadi alat ukur lainnya keberhasilan program ini. Terakhir, adanya keterlibatan pemerintah Kota Pekanbaru (Kesbangpol, Kelurahan Tanah Datar, masyarakat Pekanbaru serta mahasiswa) secara aktif untuk mengambil peran sebagai partisipan dalam kegiatan yang bersinggungan dengan aktivitas yang menunjang keberadaan dan sosialisasi pengungsi di kota ini.

\section{HASIL DAN KETERCAPAIAN}

\section{Gambaran umum pengungsi dan pencari suaka}

Pekanbaru merupakan salah satu kota yang menampung pengungsi dan pencari suaka di Indonesia. Terdapat hampir 1.000 pengungsi yang berasal dari berbagai negara, di antaranya Afganistan, Iran, Irak, Myanmar, Palestina dan lainnya. Keberadaan mereka di Pekanbaru untuk menunggu penempatan di negara yang mau menerima keberadaan mereka sebagai warga negara. Hanya saja setelah ditempatkan sementara di kota ini selama 3 (tiga) hingga 7 (tujuh) tahun, hanya sebagian kecil yang mendapatkan penempatan di negara tujuannya. Sementara ratusan lainnya masih menunggu tanpa kepastian waktu, jaminan akan ditempatkan di negara tujuan, ketiadaan jaminan untuk meperoleh sebagian hak-hak dasar seperti pekerjaan, menikah dan berketurunan, Pendidikan menengah dan tinggi serta mobilitas yang lebih luas.

Kegiatan pengabdian ini dapat menjadi proyek percontohan dan bagian dari misi kemanusiaan, pengenalan kebudayaan dan pada akhirnya interaksi dan integrasi antara kebudayaan dan kebangsaan yang beragam ini dapat meminimalisasi potensi konflik di Pekanbaru. Di sisi lain integrasi sosial dan pengetahuan untuk saling mengetahui dan memahami antara imigran dan masyarakat Pekanbaru dapat difasilitasi melalui langkahlangkah sederhana seperti pengenalan kebudayaan kedua kelompok masyarakat (imigran asing dan warga Pekanbaru) melalui penggalian potensi, promosi-eksebisi potensi yang dimiliki, pelatihan serta kegiatan integrasi sosial lainnya.

\section{Tingkat ketercapaian sasaran program}

Pengenalan tentang keberadaan pengungsi dilakukan kepada masyarakat dan kelompok mahasiswa di Pekanbaru. Ada empat bentuk kegiatan pengenalan yang dilakukan. Pertama, dalam bentuk seminar terbatas dengan peserta adalah civitas akademika Universitas Riau melibatkan perwakilan UNHCR dari Jakarta dan Pekanbaru. Kedua, dalam bentuk seminar dalam jaringan difasilitasi oleh International Organisation for Migration (IOM) diikuti dosen, mahasiswa dan masyarakat luas terkait keberadaan pengungsi di Indonesia. Ketiga, diskusi dalam jaringan bersama perwakilan IOM di Indonesia dan Pekanbaru tentang beragam potensi pengungsi yang dapat dikembangkan dan selama ini sudah dilakukan di berbagai tempat di Indonesia seperti di Jakarta dan Pekanbaru. Terakhir, Focus Group Discussion (FGD) dengan pihak terkait mulai dari pengungsi itu sendiri, IOM, UNHCR, Kesbangpol Kota Pekanbaru, mahasiswa dan Lurah Kelurahan Tanah Datar Pekanbaru. 
Banyak potensi yang dimiliki pengungsi. Sebelum mereka menyelamatkan diri, banyak di antara mereka yang memiliki profesi dan keahlian, misalnya dosen, guru, dokter, pengacara, akuntan, wartawan atau lainnya. Sebagian dari mereka memiliki keahlian khusus seperti juru masak, pelukis, pekebun/petani, dan juga profesi lainnya. Beberapa kegiatan yang dilakukan pengungsi di Pekanbaru di antaranya pelatihan melukis, pelatihan bercocok tanam, menjahit untuk kegiatan sosial. Akan tetapi mereka terikat dengan ketentuan hukum tentang larangan bekerja secara permanen ketika mereka berada di penampungan, terutama negara yang tidak merativikasi aturan internasional tentang perlindungan pengungsi. Artinya, mereka tidak boleh bekerja terutama di sektor-sektor formal karena terkait dengan status yang mereka sandang. Walaupun demikian, keberadaan mereka di Pekanbaru wajib diakui, dilindungi dan dimanusiakan.

Pandemi Covid-19 telah menghambat pelaksanaan kegiatan pengabdian masyarakat, apalagi dengan status Kota Pekanbaru yang termasuk zona merah. IOM, sebagai lembaga internasional yang turut mengatur penanganan pengungsi dan pencari suaka di Pekanbaru, tidak memberikan izin melaksanakan kegiatan berkumpul secara tatap muka secara langsung. Kegiatan hanya dapat dilakukan dalam bentuk daring atau online. Sosialisasi bersama UNHCR dan IOM pun diadakan melalui aplikasi Zoom.

Dalam pelaksanaannya, pengungsi dan pencari suaka dilibatkan dalam kegiatan membuat dan memasak makanan khas serta unik dan karya seni lukis untuk diperkenalkan kepada masyarakat Pekanbaru. Sejumlah produk khas kuliner seperti nasi Briyani dan nasi Basmati adalah produk makanan yang dibuat komunitas pengungsi asal Afghanistan dan diperkenalkan kepada masyarakat. Demikian pula dengan produk lukisan yang merupakan karya seni sejumlah seniman pengungsi juga disosialisikan kepada masyarakat. Kedua produk ini dipasarkan bersempena perayaan Hari Ulang Tahun Republik Indonesia pada tanggal 17 Agustus 2020. Kegiatan pemasaran tersebut tanpa melibatkan para pengungsi dan pencari suaka langsung, hanya karya lukisan dan masakan khas negara.

Dengan demikian, hasil dari kegiatan pengabdian masyarakat ini dapat diketahui bahwa para pengungsi dan pencari suaka sebenarnya dapat beradaptasi dengan masyarakat sekitar, meskipun memiliki hambatan dalam berkomunikasi. Lebih lanjut, dari produk kuliner dan lukisan yang dipamerkan dan dipasarkan tampak bahwa para pengungsi dan pencari suaka memiliki potensi dalam mengembangkan kemampuan ekonomi mereka. Permasalahan sekarang adalah pemberian izin dan akses terhadap produk-produk yang mereka hasilkan ke tengah-tengah masyarakat.

\section{KESIMPULAN}

Kegiatan pengabdian kepada masyarakat dalam bentuk pelatihan dan pendampingan kewirausahaan telah berhasil jika dikaitkan dengan tercapainya tujuan kegiatan pengabdian. Hasil utama dari pelaksanaan kegiatan pengabdian ini yakni berupa pameran dan pemasaran produk telah menunjukkan bahwa keberadaan pengungsi dan pencari suaka dapat diterima oleh masyarakat sekitar. Kemampuan mereka dalam menghasilkan produkproduk yang bernilai jual, juga telah menunjukkan bahwa mereka dapat meningkatkan kemampuan ekonomi mereka jika diberi kesempatan.

Ketidakpastian untuk diterima di negara ketiga telah menimbulkan permasalahan bukan saja pada para pengungsi dan pencari suaka itu sendiri, tapi juga bagi masyarakat sekitar tempat penampungan. Meskipun demikian, permasalahan ini dapat diminimalisir dengan memaksimalkan berbagai keahlian yang bisa digunakan untuk mengembangkan potensi ekonomi mereka, juga untuk mendekatkan mereka dengan warga sekitar. Di samping itu, keahlian mereka tersebut dapat juga dimanfaatkan untuk pengembangan ekonomi di sektor riil masyarakat. Untuk itu, diperlukan berbagai inisiatif yang dapat membantu menjawab permasalahan tersebut, salah satunya dengan mengadakan pelatihan dan pendampingan kewirausahaan.

\section{UCAPAN TERIMA KASIH}

Kegiatan pelatihan dan pendampingan kewirausahaan sebagai bentuk pengabdian kepada masyarakat dapat terlaksana berkat dukungan dana DIPA LPPM Universitas Riau Tahun anggaran 2020. Untuk itu, kami tim pengabdian mengucapkan terima kasih kepada Lembaga Penelitian dan Pengabdian Masyarakat Universitas Riau, begitu juga UNHCR, IOM dan Kesbangpol beserta staf atas dukungannya pada kegiatan pengabdian kepada masyarakat ini serta mahasiswa yang tergabung dalam Kuliah Kerja Nyata Terintegrasi 2020. 


\section{DAFTAR PUSTAKA}

Akbar, Yanuar. 2014. Metodologi dan Teori Hubungan Internasional. Bandung: Reflika Aditama

Moleong, Lexi J, 2000. Metode Penelitian Kualitatif, Bandung: Remaja Rosdakarya.

Nawawi, Hadari, 1990. Metode Penelitian Bidang Sosial, Yogyakarta: Gadjah Mada University Press

Aisya, Firdausyi, Sheila. 2019. "Strategi aktor internasional dan lokal dalam mengatasi permasalahan pengungsi di sidoarjo tahun 2012 hingga kuartal pertama 2019. Surabaya: Hubungan Internasional, Fakultas Ilmu Sosial dan Ilmu Politik, Universitas Airlangga

Danela, Rizky Okto. 2013. Potret Komunitas Grunge (Studi Pada Komunitas Kaum Kucel di Bandar Lampung). Lampung: Universitas Lampung.

Sari, Karlina M, 2009. Peran Library Lovers Club (LLC) dalam Mengembangkan Perpustakaan Sekolah di SMAN 49 Jakarta. Jakarta: Universitas Indonesia https://eprints.walisongo.ac.id/3590/3/102411010_Bab2.pdf diakses pada tanggal 5 Desember 2019 pukul 00.15 WIB

Secretariat Division Statistics, 2017. Handbook on Measuring International Migration through Population Censuses. New York: Department of Economic and Social Affairs of United Nations. Diakses melalui https://millenniumindicators.un.org/unsd/statcom/48th-session/documents/BG-4a-Migration-Handbook-E.pdf pada tanggal 6 Desember 2019 pukul 17.30 WIB

Staff of Programme Support and Management UNHCR. (2015) Information Management Toolkit. Geneva: Field Information and Coordination Support Section. Diakses melalui https://data.unhcr.org/imtoolkit/upload/files/toolkitPDF/eng/Information\%20Management\%20Toolkit_\%20Aug \%20201.pdf pada tanggal 6 Desember 2019 16.00 WIB

http://www.depkop.go.id/uploads/tx_rtgfiles/KOP08KEPMEN_1998_351KEPMXII1998_JUKLAK_USP.PDF diakses pada tanggal 5 Desember 2019 pukul 22. 57 WIB

https://artikbbi.com/komunitas/ diakses pada tanggal 4 Desember 2019 pukul 23.56 WIB

https://publications.iom.int/system/files/pdf/mpp29.pdf diakses pada 5 Desember 2019 pukul 00.00 WIB

https://ugm.ac.id/id/berita/16407-akses.pekerjaan.krusial.bagi.pengungsi diakses pada tanggal 5 Desember 2019 pukul $00.06 \mathrm{WIB}$

https://www.sdg2030indonesia.org/ diakses pada 5 Desember 2019 pukul 20.00 WIB

https://www.sdg2030indonesia.org/page/1-tujuan-sdg diakses pada 1 Desember 2019 pukul 17.30 WIB

https://www.unhcr.org/id/pencari-suaka diakses pada tanggal 6 Desember 2019 pukul 07.00 WIB

https://kemlu.go.id/portal/id/read/88/halaman_list_lainnya/isu-isu-kemanusiaan diakses pada tanggal 6 Desember 2019 pukul 07.30 WIB

https://www.liputan6.com/global/read/4019232/nasib-pengungsi-terlunta-lunta-di-indonesia-ditolak-negeriimpian\#: :text=Jumlah\%20Pengungsi\%20di\%20Indonesia,yang\%20berjumlah\%20sekitar\%2014.300\%20orang diakses pada tanggal 6 Desember 2019 pukul 08.00 WIB

https://www.validnews.id/Infografis-Deteni-dan-Pengungsi-13-Rudenim-di-Indonesia-dv diakses pada tanggal 6 Desember 2019 pukul 08.15 WIB

https://www.suara.com/news/2019/07/02/133526/ratusan-anak-imigran-di-pekanbaru-akan-ditampung-di-sekolahnegeri?page=all diakses pada tanggal 6 Desember 2019 pukul 08.20 WIB

https://www.goriau.com/berita/baca/100-pengungsi-di-pekanbaru-demo-rudenim-minta-perbaikanfasilitas.html\#: :text=Jumlah\%20pengungsi\%20di\%20Pekanbaru\%20kini,tempat\%20sudah\%20terakomodir\%2 C\%E2\%80\%9D\%20katanya diakses pada tanggal 6 Desember 2019 pukul 09.15 WIB 